\title{
Coupled cobalt-doped molybdenum carbide@N-doped carbon nanosheets/nanotubes supported on nickel foam as a binder-free electrode for overall water splitting
}

\author{
Jiangnan Xing a , Fei Lin a, Liutao Huang a, Yuchang Si b, ${ }^{\text {,* }}$, Yijing Wang a, Lifang Jiao a,* \\ a Key Laboratory of Advanced Energy Materials Chemistry (Ministry of Education), Renewable Energy Conversion and Storage Center, \\ College of Chemistry, Nankai University, Tianjin 300071, China \\ ${ }^{\mathrm{b}}$ Logistics University of People's Armed Police Force, Tianjin 300309, China
}

\section{A R T I C L E I N F O}

\section{Article history:}

Received 31 March 2019

Accepted 10 May 2019

Published 5 September 2019

\section{Keywords:}

Molybdenum carbide

Cobalt doping

Self-supported electrode

Overall water splitting

\begin{abstract}
A B S T R A C T
In an attempt to develop low-cost, non-noble-metal bifunctional electrocatalysts for water electrolysis in alkaline media, cobalt-doped molybdenum carbide@N-doped carbon nanosheets/nanotubes were fabricated by using $\mathrm{C}_{3} \mathrm{~N}_{4}$ as the carbon source on a 3D porous nickel foam substrate. Benefiting from the optimized electronic structure and enhanced mass and charge transport, as well as the 3D conducting pathway, $\mathrm{Mo}_{x} \mathrm{Co}_{y} @ \mathrm{~N}-\mathrm{CNSs} / \mathrm{CNTs}$ shows superior performance towards both the hydrogen evolution reaction (HER) and oxygen evolution reaction (OER) in an alkaline medium. The optimal electrocatalyst is $\mathrm{Mo}_{2} \mathrm{Co}_{1} @ \mathrm{~N}-\mathrm{CNSs} / \mathrm{CNTs}$, which reveals a current density of $10 \mathrm{~mA} \mathrm{~cm}^{-2}$ at the low overpotentials of $99 \mathrm{mV}$ and $300 \mathrm{mV}$ for the HER and OER, respectively, and a relatively low cell voltage $(1.63 \mathrm{~V})$ for the overall water electrolysis. The method of optimizing the composition and nanostructure of a material provides a new avenue for the development and utilization of high-performance electrocatalysts.
\end{abstract}

(C) 2019, Dalian Institute of Chemical Physics, Chinese Academy of Sciences. Published by Elsevier B.V. All rights reserved.

\section{Introduction}

The rapid growth in energy consumption and the associated environmental issues are driving people to develop sustainable and environment-friendly alternative energy sources that can replace the exhaustible fossil fuels. Hydrogen energy is widely considered in this regard because of its environmental friendliness, zero emission of global warming gases, and a high calorific value [1-3]. Electrochemical splitting of water into oxygen and hydrogen is a promising way of realizing it on a practically large scale $[4,5]$. The electrochemical water splitting includes two half-cell reactions: the hydrogen evolution reaction (HER), which occurs at the cathode, and the oxygen evolution reaction (OER), which occurs at the anode, both of which suffer from unavoidable dynamic overpotentials and therefore require electrocatalysts to lower the reaction energy barriers $[4,6]$. Currently, the state-of-the-art catalysts for the HER and OER are Pt-based and Ir/Ru-based compounds, respectively [7,8]. However, their high cost and low earth abundance significantly limit their widespread applications. Therefore, the development of high-efficiency noble-metal-free catalysts that facilitate the HER or OER or both is of great significance. Recently, di-

\footnotetext{
* Corresponding author. Tel/Fax:+86-22-23504527; E-mail: jiaolf@nankai.edu.cn

** Corresponding author. Tel/Fax:+86-22- 84876282;E-mail: siyuch@163.com

This work was financially supported by the National Natural Science Foundation of China $(51622102,51571124,21421001)$, the 111 Project (B12015), the Natural Science Foundation of Tianjin (18ZXJMTG00040, 16PTSYJC00030), and the Fundamental Research Funds for the Central Universities.
}

DOI: S1872-2067(19)63406-6 | http://www.sciencedirect.com/science/journal/18722067 | Chin. J. Catal., Vol. 40, No. 9, September 2019 
verse catalysts have been developed as non-precious electrocatalysts for the HER or OER [9-13]. Unfortunately, very few electrocatalysts can be used for both the HER and OER in the same electrolyte. In view of this, we focused on the exploration of low cost and highly efficient bifunctional electrocatalysts.

Molybdenum carbide as an earth-abundant and inexpensive catalyst for the HER has recently attracted a great amount of attention owing to its Pt-like d-band electronic structure, high hydrogen-adsorption ability, high electrical conductivity, and good chemical stability [14-17]. Therefore, extensive efforts have been devoted to developing molybdenum carbide with various nanostructures. For example, 1D nanoporous molybdenum carbide nanowires [18], 2D layered $\mathrm{Mo}_{2} \mathrm{CT}_{x}$ MXenes [19], hierarchical $\beta-\mathrm{Mo}_{2} \mathrm{C}$ nanotubes organized by ultrathin 2D nanosheets [20], and porous molybdenum carbide nano-octahedrons [21] have been synthesized and used as efficient HER electrocatalysts. However, challenges still remain that prevent them from competing with the Pt-group metals. A volcano-shaped correlation between the HER activity and H-metal bond strength, calculated by density functional theory, shows that molybdenum carbide displays a strong H-bonding ability, whereas Co exhibits a weak H-bonding ability [22,23]. Accordingly, it has been demonstrated that chemically coupling Co with molybdenum carbide can lead to a relatively moderate $\mathrm{H}$-metal binding energy, which improves the intrinsic activity of the electrocatalyst towards the HER [24,25]. Despite these encouraging results, molybdenum carbide has received minimal attention as an OER electrocatalyst. Co-based catalysts have been reported to be efficient and stable OER electrocatalysts for alkaline water electrolysis [26,27]. In view of the above considerations, this catalyst design is supposed to be also capable of boosting the OER activity owing to the presence of the OER-active Co. In particular, electrocatalytic materials synthesized through direct growth on conductive substrates can be directly used as a working electrode and avoid the use of polymer binders, which may block the active sites and mass transfers, apart from increasing the electron transfer resistance. However, there are few molybdenum-carbide-based electrocatalysts that are directly grown on substrates without using binders.

Herein, we propose a facile and controllable strategy to develop highly efficient and stable Co-doped molybdenum carbide@N-doped carbon nanosheets/nanotubes by direct growth on a $3 \mathrm{D}$ conductive $\mathrm{Ni}$ foam, acting as a self-supported electrode, for the HER and OER for the first time. By simply regulating the concentration of cobalt nitrate in the precursor solution, a series of Co-doped molybdenum carbide@N-doped carbon nanosheets/nanotubes were synthesized. Furthermore, our study revealed that the electrocatalytic activities of the hybrid catalysts are strongly related to the Co doping amount. As expected, the optimal Mo2 $\mathrm{Co}_{1} @ \mathrm{~N}-\mathrm{CNS} / \mathrm{CNT}$ sample exhibits the best catalytic performance. To obtain a current density of $10 \mathrm{~mA} \mathrm{~cm}^{-2}$, overpotentials of only $99 \mathrm{mV}$ and $300 \mathrm{mV}$ are required for the electrocatalytic HER and OER, respectively, and a relatively low cell voltage $(1.63 \mathrm{~V})$ for the overall water electrolysis in $1 \mathrm{M} \mathrm{KOH}$ electrolyte. The excellent catalytic performance could be attributed to the high intrinsic activity arising from the combination of Co with $\mathrm{MoC}$, as well as to the exposure of the more active sites provided by the 3D structure and to the rich $\mathrm{N}$ content of pyridine.

\section{Experimental}

\subsection{Chemicals}

Cobalt nitrate hexahydrate $\left(\mathrm{Co}\left(\mathrm{NO}_{3}\right)_{2} \cdot 6 \mathrm{H}_{2} \mathrm{O}\right)$, potassium hydroxide $(\mathrm{KOH})$, and iridium oxide $\left(\mathrm{IrO}_{2}\right)$ were all purchased from Aladdin. Ammonium molybdate $\left(\left(\mathrm{NH}_{4}\right)_{6} \mathrm{Mo}_{7} \mathrm{O}_{24} \cdot 4 \mathrm{H}_{2} \mathrm{O}\right)$ was purchased from Tianjin Feng Chuan Chemical Reagent Technology Ltd. Sodium $n$-dodecyl sulfate (SDS, $\mathrm{NaC}_{12} \mathrm{H}_{25} \mathrm{SO}_{4}$ ) was purchased from Meryer Chemical Technology Co. Ltd. Concentrated hydrochloric acid $(\mathrm{HCl}, 37 \%)$ was purchased from Tianjin Chemical Reagent Wholesale Company. Platinum on carbon (20 wt\% Pt/C) was purchased from Alfa Aesar Chemical Co. Ltd. All chemical reagents were used as-received without further purification and all aqueous solutions were prepared with the ultrapure water obtained from a Millipore system. The Ni foam (about $2 \mathrm{~cm} \times 4 \mathrm{~cm}$ ) used was cleaned several times by using diluted hydrochloric acid, ethanol, and deionized water.

\subsection{Synthesis of $\mathrm{Mo}_{x} \mathrm{Co}_{y} \mathrm{ONSs@NF}$}

In a typical preparation, $20 \mathrm{mmol} \mathrm{L}-1\left(\mathrm{NH}_{4}\right)_{6} \mathrm{Mo}_{7} \mathrm{O}_{24} \cdot 4 \mathrm{H}_{2} \mathrm{O}$, $10 \mathrm{mmol} \mathrm{L}^{-1} \mathrm{Co}\left(\mathrm{NO}_{3}\right)_{2} \cdot 6 \mathrm{H}_{2} \mathrm{O}$, and $100 \mathrm{mmol} \mathrm{L}^{-1} \mathrm{SDS}$ were dissolved in $30 \mathrm{~mL}$ deionized water at room temperature to form a uniform solution. The aqueous solution and the NF were subsequently transferred into a $50 \mathrm{~mL}$ Teflon-lined stainless steel autoclave. The autoclave was then heated at $100{ }^{\circ} \mathrm{C}$ for 18 h. After cooling to room temperature naturally, the Ni foam with the precursor was cleaned with deionized water several times and dried at $60{ }^{\circ} \mathrm{C}$ for $8 \mathrm{~h}$ in an oven. $\mathrm{Mo}_{2} \mathrm{Co}_{0} \mathrm{O} \mathrm{NSs} @ \mathrm{NF}$, Mo2 $\mathrm{Co}_{22} \mathrm{O}$ NSs@NF, Mo2 $\mathrm{Co}_{0.5} \mathrm{O}$ NSs@NF, Mo2 $\mathrm{Co}_{2} \mathrm{O}$ NSs@NF, and $\mathrm{Mo}_{0} \mathrm{Co}_{2} \mathrm{O}$ NSs@NF were prepared as control samples by using the same method as that used for synthesizing $\mathrm{Mo}_{2} \mathrm{Co}_{1} \mathrm{O}$ NSs@NF, except for changes in the concentrations of $\mathrm{Co}\left(\mathrm{NO}_{3}\right)_{2} \cdot 6 \mathrm{H}_{2} \mathrm{O}$ and $\left(\mathrm{NH}_{4}\right)_{6} \mathrm{Mo}_{7} \mathrm{O}_{24} \cdot 4 \mathrm{H}_{2} \mathrm{O}$ from 10 and $20 \mathrm{mmol}$ $\mathrm{L}^{-1}$, respectively, to $0,2.5,5,20$, and $0 \mathrm{mmol} \mathrm{L}^{-1}$.

\subsection{Synthesis of MoxCoy@N-CNS/CNTs}

$2 \mathrm{~cm} \times 2 \mathrm{~cm} \mathrm{Mox} \mathrm{Co}_{y} \mathrm{O}$ NSs@NF and $0.032 \mathrm{~g} \mathrm{C}_{3} \mathrm{~N}_{4}$ were placed at two separate positions in two interlocking quartz boats with a separation distance of about $3 \mathrm{~cm}$. $\mathrm{C}_{3} \mathrm{~N}_{4}$ was placed on the upstream side in a horizontal tube furnace. The furnace was then carburized at $800{ }^{\circ} \mathrm{C}$ for $3 \mathrm{~h}$ at a heating rate of $5^{\circ} \mathrm{C} \mathrm{min}^{-1}$ in Ar flow.

\subsection{Characterizations}

Scanning electron microscopy (SEM) and transmission electron microscopy (TEM) investigations were carried out on JEOL JSM-7500F and Talos F200X G2 AEMC instruments, respectively. X-ray diffraction (XRD) was performed on a Rigaku 
D/Max-2500. The Co and Mo contents of $\mathrm{Mo}_{x} \mathrm{Co}_{y} @ \mathrm{~N}-\mathrm{CNS} / \mathrm{CNTs}$ were measured by inductively coupled plasma (ICP; PerkinElmer Optima 8300). The Raman spectrum was collected on a Renishaw inVia at the excitation laser wavelength of $514.5 \mathrm{~nm}$. X-ray photoelectron spectroscopy (XPS) was carried out on a Kratos Analytical Ltd. Axis Ultra DLD.

\subsection{Electrochemical measurements}

All electrochemical measurements were performed on a CHI $760 \mathrm{E}$ electrochemical workstation by using the standard three-electrode setup at room temperature $\left(\sim 25{ }^{\circ} \mathrm{C}\right)$. The as-obtained composite, a graphite rod, and saturated calomel electrode (SCE) were used as the working electrode, counter electrode, and reference electrode, respectively. The electrolyte was a $1 \mathrm{~mol} \mathrm{~L}^{-1} 1 \mathrm{M} \mathrm{KOH}$ solution that was degassed by bubbling $\mathrm{Ar}$ and $\mathrm{O}_{2}$ for more than $30 \mathrm{~min}$ before each HER and OER test, respectively. For comparison, pure $\mathrm{Ni}$ foam, $\mathrm{Pt} / \mathrm{C}$, and $\mathrm{IrO}_{2}$ supported on $\mathrm{Ni}$ foams $\left(0.4 \mathrm{mg} \mathrm{cm}{ }^{-2}\right)$ were also investigated. Linear sweep voltammetry polarization curves were obtained with iR compensation at a scan rate of $5 \mathrm{mV} \mathrm{s}^{-1}$. All the potentials were referenced to the reversible hydrogen electrode (RHE) based on the formula $\left(E_{v s . ~ R H E}=E_{v s . ~ S C E}+E_{\text {SCE }}+0.059 \mathrm{pH}\right)$. Electrochemical impedance spectroscopy (EIS) was carried out in the form of AC impedance measurements in the frequency range $10^{5} \mathrm{kHz}$ to $10^{-1} \mathrm{~Hz}$. Stability tests in the form of chronopotentiometry were performed at a constant current density. For the overall water splitting, the as-obtained self-supported electrode was used as both the anode and cathode.

\section{Results and discussion}

The Co-doped molybdenum carbide@N-doped carbon nanosheets/nanotubes were prepared by a two-step method (for details, refer to the Experimental section). In the first step, the precursors were synthesized by hydrothermal method (and denoted as $\mathrm{Mo}_{x} \mathrm{Co}_{y} \mathrm{O} \mathrm{NSs} @ \mathrm{NF}$, where $x$ and $y$ represent the concentrations of $\mathrm{Co}\left(\mathrm{NO}_{3}\right)_{2} \cdot 6 \mathrm{H}_{2} \mathrm{O}$ and $\left(\mathrm{NH}_{4}\right)_{6} \mathrm{Mo}_{7} \mathrm{O}_{24} \cdot 4 \mathrm{H}_{2} \mathrm{O}$, respectively, after 100-fold expansion). The morphologies of the precursors were investigated by SEM (Fig. S1). As can be seen, when only the Co source (MooCo2 $\mathrm{O}$ NSs@NF) is present, the precursor exhibits a thicker pleated structure, while the other precursors are all 2D nanosheet arrays that are bound to the Ni foam. In addition, compared with $\mathrm{Mo}_{2} \mathrm{Co}_{0} \mathrm{O} \mathrm{NSs} @ \mathrm{NF}$, the nanosheet of the precursor with the Co source was significantly thicker. It is worth mentioning that the introduction of SDS during the hydrothermal process can result in the formation of an oil-water interface, so that the precursor can form 2D nanosheet arrays [28,29]. Subsequently, these precursors were subjected to a carbonization process in Ar atmosphere at 800 ${ }^{\circ} \mathrm{C}$ with $\mathrm{C}_{3} \mathrm{~N}_{4}$ as the source of both $\mathrm{C}$ and $\mathrm{N}$ (named as $\mathrm{Mo}_{X-}$ Coy@N-CNS/CNT). It can be found that, except for the XRD pattern of MooCo2@N-CNS/CNT, which can be indexed to Co metal, the incorporation of Co into the precursors does not induce the formation of new crystalline phases in the hybrids (Fig. S2). Noticeably, the pattern of MoC in $\mathrm{Mo}_{2} \mathrm{Co}_{y} @ \mathrm{~N}-\mathrm{CNS} / \mathrm{CNT}$ (where $y$ ranges from 0.25 to 2 ) catalyst shows a slight shift to higher diffraction angles in comparison with that of bare MoC (Mo2Co0@N-CNS/CNT). The shift in the diffraction peaks is attributed to the shrinkage of the MoC unit cell, which is a result of the replacement of some Mo atoms with the smaller Co atoms, which in turn suggests that Co was successfully doped into MoC [25]. We further determined the Co:Mo molar ratio in $\mathrm{Mo}_{x} \mathrm{Co}_{y} @ \mathrm{~N}-\mathrm{CNS} / \mathrm{CNT}$ by using ICP (Table S1; details can be found in Supporting Information). The morphologies of the as-prepared $\mathrm{Mo}_{x} \mathrm{Co}_{y} @ \mathrm{~N}-\mathrm{CNS} / \mathrm{CNT}$ were also investigated by SEM (Fig. S3; details in Supporting Information).

We explored the morphology, structure, and composition of the representative $\mathrm{Mo}_{2} \mathrm{Co}_{1} @ \mathrm{~N}-\mathrm{CNS} / \mathrm{CNT}$ hybrid catalyst. From the low-magnification SEM image displayed in Fig. 1a, it can be observed that the skeletons of the Ni foam are uniformly covered by the final product. A higher-magnification SEM image reveals that the morphology corresponds to a 3D structure that is formed by interlacing of the 2D nanosheets and the 1D nanowires (Fig. 1b). Such a structure can provide a large number of exposed active sites and effectively promote mass transfer during the electrocatalysis process. The high-magnification TEM image reveals that the nanosheets are composed of nanoparticles and that the nanowires are hollow $\mathrm{C}$ nanotubes that contain nanoparticles (Fig. 1c and S4). In the high-resolution TEM image (Fig. 1d), the clear lattice spacing of $\sim 0.18 \mathrm{~nm}$ is coincident with the interplanar spacing of MoC(101), which suggests that the composition of the nanoparticles is MoC. In accordance with the XRD results, Co was not observed in the TEM analysis as well. Furthermore, scanning transmission electron microscopy (STEM) images and the corresponding elemental maps show that $\mathrm{Co}, \mathrm{Mo}, \mathrm{N}, \mathrm{C}$, and $\mathrm{O}$ elements are uniformly spatially distributed across the selected nanosheet

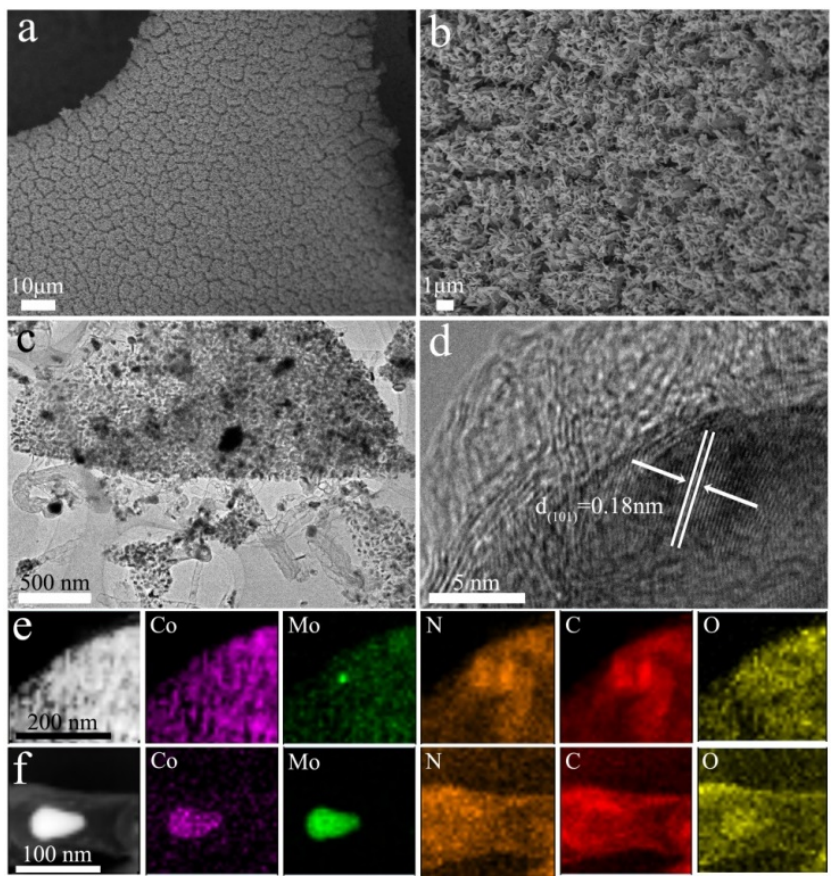

Fig. 1. (a, b) SEM images, (c) TEM image, (d) HRTEM image, (e, f) STEM and the corresponding elemental mapping images of $\mathrm{Mo}_{2} \mathrm{Co}_{1} @ \mathrm{~N}-\mathrm{CNS} / \mathrm{CNT}$. 
and hollow nanotube (Fig. 1e and 1f), which suggest homogeneous Co doping into MoC. It is worth mentioning that the 0 element may originate from the inevitable oxidation of the materials exposed to air [30,31].

The Raman spectrum displays the well-known D-band (at $1354 \mathrm{~cm}^{-1}$ ) and G-band (at $1589 \mathrm{~cm}^{-1}$ ) of graphene (Fig. 2a). Moreover, the $I_{\mathrm{D}}: I_{\mathrm{G}}$ value is 0.85 , which is indicative of its high degree of graphitization, which can facilitate the transport of electrons to the active sites. In addition, we used XPS to investigate the surface chemical environment of the material. The XPS survey spectrum of $\mathrm{Mo}_{2} \mathrm{Co}_{1} @ \mathrm{~N}-\mathrm{CNS} / \mathrm{CNT}$ reveals the existence of $\mathrm{Co}, \mathrm{Mo}, \mathrm{N}, \mathrm{C}$, and $\mathrm{O}$ elements, which is consistent with the TEM-EDX map (Fig. S5a). As can be seen, the high-resolution Mo $3 d$ XPS pattern is deconvoluted into six peaks that are ascribed to $\mathrm{Mo}^{2+}, \mathrm{Mo}^{4+}$, and $\mathrm{Mo}^{6+}$ (Fig. 2b). The $\mathrm{Mo}^{2+}$ species corresponds to $\mathrm{MoC}$ and is considered to be the active center during the electrocatalytic process [32]. The $\mathrm{Mo}^{4+}$ and $\mathrm{Mo}^{6+}$ species can be attributed to the surface oxidation of MoC when exposed to air [30,31]. Fig. 2c presents the high-resolution XPS pattern of Co $2 p$, and the two peaks located at 779.8 and $795.6 \mathrm{eV}$ correspond to Co $2 p_{3 / 2}$ and Co $2 p_{1 / 2}$, respectively. Noticeably, the peak position of Co $2 p_{3 / 2}$ is between those of $\mathrm{Co}^{0} 2 p_{3 / 2}(778.3 \mathrm{eV})$ and $\mathrm{CoO}_{x}(781.3 \mathrm{eV})$, which suggests partial oxidation of Co [33]. The N $1 s$ profile (Fig. 2d) can be deconvoluted into three peaks that correspond to the Mo- $\mathrm{N}$ bonding phase (394.3 eV), pyridinic $\mathrm{N}(397.9 \mathrm{eV})$, and graphitic $\mathrm{N}(401.4 \mathrm{eV})$, with the proportions being $2.6 \%, 79.88 \%$, and $17.52 \%$, respectively. The high concentration of pyridinic $\mathrm{N}$ can change the intrinsic chemical inertness and electronic structure of the adjacent $\mathrm{C}$ atoms, thus promoting the adsorption of the intermediates of the water oxidation process $\left(\mathrm{OH}^{-}, \mathrm{OOH}^{-}\right)$as the rate-determining step [24]. The C $1 s$ XPS pattern shows two peaks 284.6 and $285.5 \mathrm{eV}$ that correspond to Mo-bound $\mathrm{C}$ and $\mathrm{C}-\mathrm{N}$, respectively, which indicate successful doping of $\mathrm{N}$ element into the C matrix (Fig. S5b) [34]. Furthermore, we used ultraviolet photoelectron spectroscopy to investigate the valance bands of the samples with and without Co doping (Fig. S6).
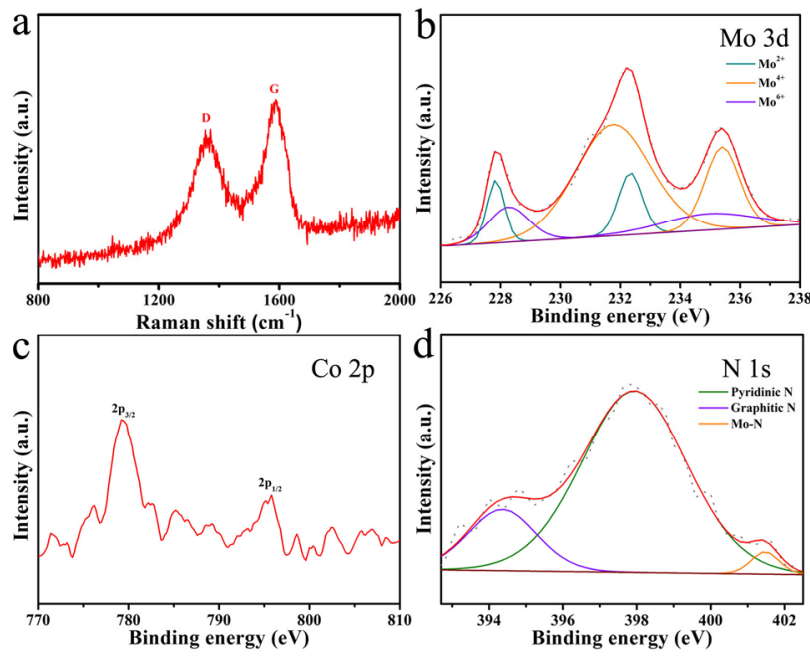

Fig. 2. (a) Raman spectrum and (b) Mo $3 d$, (c) Co $2 p$, and (d) $\mathrm{N} 1 s$ high-resolution XPS spectra of $\mathrm{Mo}_{2} \mathrm{Co}_{1} @ \mathrm{~N}-\mathrm{CNS} / \mathrm{CNT}$.
The as-prepared $\mathrm{Mo}_{x} \mathrm{Co}_{y} @ \mathrm{~N}-\mathrm{CNS} / \mathrm{CNT}$ samples were directly used as the working electrode and their electrocatalytic HER performances were evaluated by using the standard three-electrode system in Ar-saturated $1 \mathrm{~mol} \mathrm{~L}^{-1} \mathrm{KOH}$ solution at the scan rate of $5 \mathrm{mV} \mathrm{s}^{-1}$ (details in the Electrochemical Measurements section). All the potentials were referenced to the RHE. Fig. 3a shows the polarization curves of $\mathrm{Mo}_{x-}$ $\mathrm{Co}_{y} @ \mathrm{~N}-\mathrm{CNS} / \mathrm{CNT}$, along with those of the benchmark 20 wt $\%$ $\mathrm{Pt} / \mathrm{C}$ and pure Ni foam, which are presented for comparison. As can be seen, commercial Pt/C exhibits optimal hydrogen evolution performance, with an overpotential of only $19 \mathrm{mV}$ required to reach the current density of $10 \mathrm{~mA} \mathrm{~cm}{ }^{-2}$, whereas the $\mathrm{Ni}$ foam displays negligible catalytic activity. Among our samples, the optimal HER catalytic activity is obtained for Mo2Co1@N-CNS/CNT, with an overpotential of only $99 \mathrm{mV}$ required to achieve a cathodic current density of $10 \mathrm{~mA} \mathrm{~cm}{ }^{-2}$, which is lower than those of bare MoC (Mo $2 \mathrm{Co}_{0} @ \mathrm{~N}-\mathrm{CNS} / \mathrm{CNT}$, $195 \mathrm{mV}$ ) and Co (MooCo2@N-CNS/CNT, 138 mV). Such an electrocatalytic activity is comparable to those of most Mo-based and Co-based catalysts that have been reported (Table S2). Furthermore, the $\mathrm{Mo}_{2} \mathrm{Co}_{y} @ \mathrm{~N}-\mathrm{CNS} / \mathrm{CNT}$ samples require $\eta_{10}$ that display the following order: $\mathrm{Mo}_{2} \mathrm{Co}_{1} @ \mathrm{~N}-\mathrm{CNS} / \mathrm{CNT}<$ $\mathrm{Mo}_{2} \mathrm{Co}_{2} @ \mathrm{~N}-\mathrm{CNS} / \mathrm{CNT}<\mathrm{Mo}_{2} \mathrm{Co}_{0.5} @ \mathrm{~N}-\mathrm{CNS} / \mathrm{CNT}<$ Mo2Co0.25@N-CNS/CNT. Increasing or decreasing the Co doping amount will lead to a lower activity of the $\mathrm{Mo}_{x} \mathrm{Co}_{y} @ \mathrm{~N}-\mathrm{CNS} / \mathrm{CNT}$ catalyst. These results indicate that Co doping can significantly improve the catalytic activity of $\mathrm{MoC}$ and that the doping amount has an obvious effect on the catalytic activity.

To obtain further insights into the HER kinetics of the catalysts, the Tafel slopes were calculated from the polarization curves by using the Tafel equation. As shown in Fig. 3b, the Tafel slope of $27.8 \mathrm{mV} \mathrm{dec}-1$ for Pt/C is consistent with the value reported in the literature, indicating the validity of the electrochemical measurements. The Tafel slope of Mor $\mathrm{Co}_{1} @ \mathrm{~N}-\mathrm{CNS} / \mathrm{CNT}$ is calculated to be $96.2 \mathrm{mV} \mathrm{dec}^{-1}$, which is larger than that of $\mathrm{Pt} / \mathrm{C}$, but superior to those of $\mathrm{Mo}_{2} \mathrm{Co}_{0} @ \mathrm{~N}-\mathrm{CNS} / \mathrm{CNT} \quad\left(115.3 \mathrm{mV} \quad \mathrm{dec}^{-1}\right) \quad$ and $\mathrm{Mo}_{0} \mathrm{Co}_{2} @ \mathrm{~N}-\mathrm{CNS} / \mathrm{CNT}$ (107.9 mV dec ${ }^{-1}$ ), which suggests faster HER kinetics. The Tafel slope of $96.2 \mathrm{mV} \mathrm{dec}^{-1}$ indicates that the HER process follows the Volmer-Heyrovsky mechanism and that the Volmer step is the rate-determining step in alkaline media $[20,24]$. The capacitance of the double layer at the solid-liquid interface was measured to estimate the electrochemical surface areas. Derived from the cyclic voltammograms obtained in $1 \mathrm{~mol} \mathrm{~L}^{-1} \mathrm{KOH}$ for various scan rates (Fig. S7), the maximum $C_{\mathrm{dl}}$ of $59.86 \mathrm{mF \quad \textrm {cm } ^ { - 2 }}$ was observed for $\mathrm{Mo}_{2} \mathrm{Co}_{1} @ \mathrm{~N}-\mathrm{CNS} / \mathrm{CNT}$ among the studied catalysts (Fig. 3c), which suggested that more active sites are available on this catalyst. The Nyquist plots given in Fig. 3d reveal that $\mathrm{Mo}_{2} \mathrm{Co}_{1} @ \mathrm{~N}-\mathrm{CNS} / \mathrm{CNT}$ generates the smallest charge transfer resistance among all the studied samples. This further proves the faster transport of charges in $\mathrm{Mo}_{2} \mathrm{Co}_{1} @ \mathrm{~N}-\mathrm{CNS} / \mathrm{CNT}$ during the electrochemical HER.

Stability is another important index for evaluating the performances of catalysts. The durability of the $\mathrm{Mo}_{2} \mathrm{Co}_{1} @ \mathrm{~N}-\mathrm{CNS} / \mathrm{CNT}$ catalyst for the HER was evaluated by chronopotentiometry measurement at the current density of 

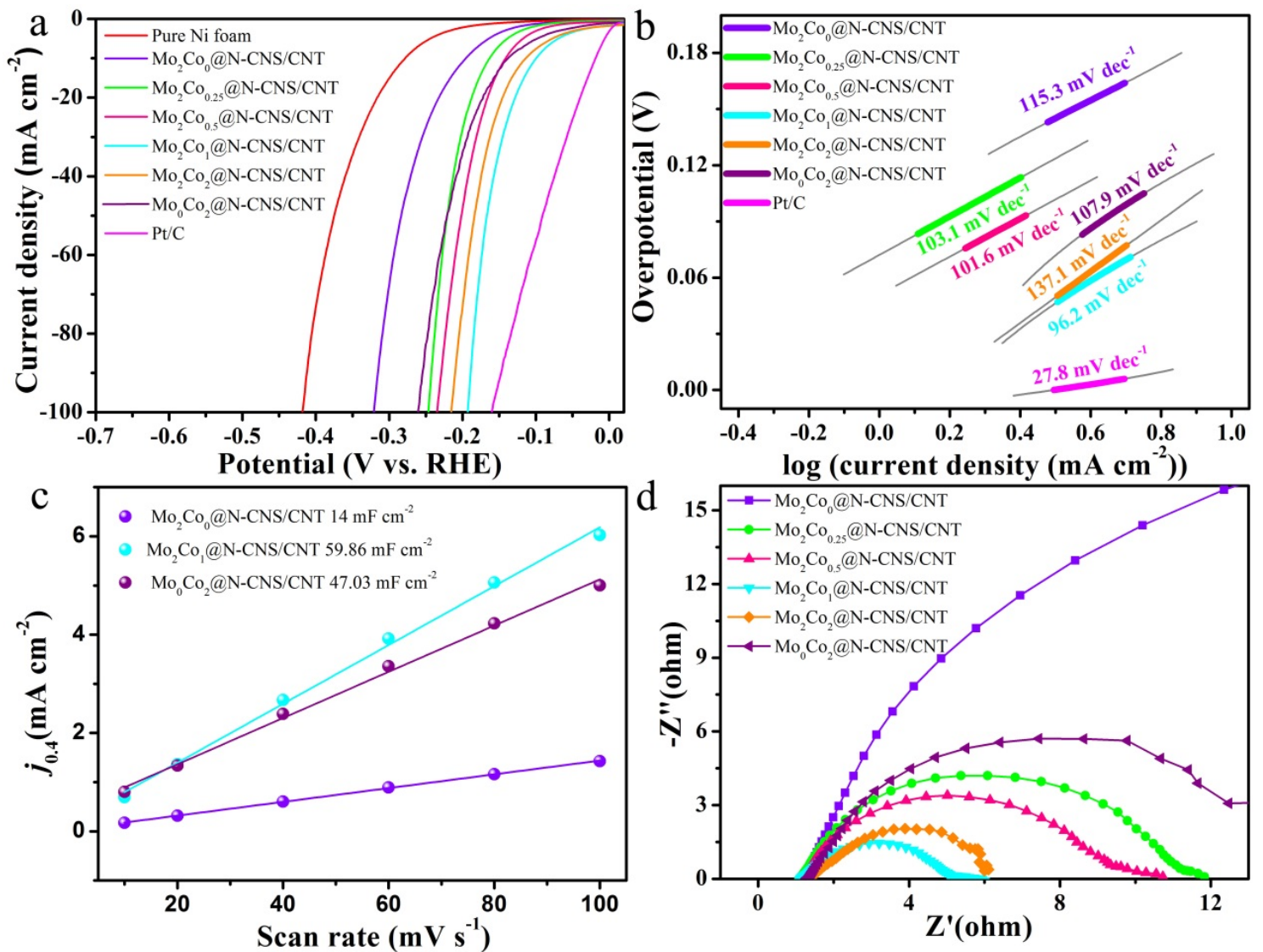

Fig. 3. Results of HER tests conducted in $1 \mathrm{~mol} \mathrm{~L}-1$ KOH. (a) Polarization curves and (b) Tafel plots of Mo $\mathrm{Mo}_{y} @ \mathrm{~N}-\mathrm{CNS} / \mathrm{CNT}$, Ni foam, and Pt/C obtained at a scan rate of $5 \mathrm{mV} \mathrm{s}^{-1}$. (c) Capacitive currents at $0.418 \mathrm{~V}$ vs. RHE as functions of scan rates for $\mathrm{Mo}_{2} \mathrm{Co}_{0} @ \mathrm{~N}-\mathrm{CNS}_{2} \mathrm{CNT}_{2} \mathrm{Mo} \mathrm{Co}_{1} @ \mathrm{~N}-\mathrm{CNS} / \mathrm{CNT}$, and Moo $\mathrm{Co}_{2} @ \mathrm{~N}-\mathrm{CNS} / \mathrm{CNT}$. (d) EIS Nyquist plots of $\mathrm{Mo}_{x} \mathrm{Co}_{y} @ \mathrm{~N}-\mathrm{CNS} / \mathrm{CNT}$ obtained at a potential of $-1.2 \mathrm{~V}$.

$10 \mathrm{~mA} \mathrm{~cm}^{-2}$. As can be seen in Fig. S8a, the overpotential undergoes no distinct change during the prolonged chronopotentiometry test for $20 \mathrm{~h}$. To determine the reason for the stability of $\mathrm{Mo}_{2} \mathrm{Co}_{1} @ \mathrm{~N}-\mathrm{CNS} / \mathrm{CNT}$, we also recorded the SEM images and XRD patterns of $\mathrm{Mo}_{2} \mathrm{Co}_{1} @ \mathrm{~N}-\mathrm{CNS} / \mathrm{CNT}$ after the HER durability test. As revealed by the SEM images (inset images in Fig. S8a), the excellent stability of Mo2 $\mathrm{Co}_{1} @ \mathrm{~N}-\mathrm{CNS} / \mathrm{CNT}$ is confirmed by the negligible changes observed in the structure before and after the long-term electrolysis of water. Furthermore, the XRD patterns of Mo2 $\mathrm{Co}_{1} @ \mathrm{~N}-\mathrm{CNS} / \mathrm{CNT}$ before and after the HER durability test indicate no obvious changes in the crystalline structure (Fig. S8b). These results confirm that the outstanding catalytic stability of the Mo2 $\mathrm{Co}_{1} @ \mathrm{~N}-\mathrm{CNS} / \mathrm{CNT}$ electrode can be attributed to the robustness of its nanostructure and to its high chemical stability.

In $1 \mathrm{~mol} \mathrm{~L}^{-1} \mathrm{KOH}$ solution purged with $\mathrm{O}_{2}$, the OER performances of the Mo $\mathrm{Co}_{y} @ \mathrm{~N}-\mathrm{CNS} / \mathrm{CNT}$ samples were also evaluated, and compared with those of pure Ni foam and the precious $\mathrm{IrO}_{2}$ catalyst. In accordance with the literature results, all the polarization curves exhibit anodic peaks between 1.3 and $1.4 \mathrm{~V}$, which are due to the oxidation of the $\mathrm{Ni}$ in the $\mathrm{Ni}$ foam substrate [35,36]. As shown in Fig. 4a, the pure Ni foam presents a relatively poor catalytic activity, requiring an overpotential as high as $460 \mathrm{mV}$ to deliver a current density of $10 \mathrm{~mA}$ $\mathrm{cm}^{-2}$. In line with the results of the electrocatalytic HER per- formances, the as-prepared $\mathrm{Mo}_{2} \mathrm{Co}_{1} @ \mathrm{~N}-\mathrm{CNS} / \mathrm{CNT}$ catalyst shows the best OER performance among all the MoxCoy@N-CNS/CNT catalysts. An overpotential of $300 \mathrm{mV}$ is required to realize the current density of $10 \mathrm{~mA} \mathrm{~cm}^{-2}$, which is significantly lower than those required for most Co-based and Mo-based electrocatalysts (Table S3). Strikingly, MozCoo@N-CNS/CNT and MooCoz@N-CNS/CNT display relatively low OER activities. To shed light on the catalytic OER kinetics, detailed Tafel analysis was carried out. As shown in Fig. 4b, the calculated Tafel slope of Mo2 $\mathrm{Co}_{1} @ N-C N S / C N T$ is $74.4 \mathrm{mV} \mathrm{dec}^{-1}$, which is 48 and $18.3 \mathrm{mV} \mathrm{dec}^{-1}$ lower than those of $\mathrm{Mo}_{2} \mathrm{Co}_{0} @ \mathrm{~N}-\mathrm{CNS} / \mathrm{CNT}$ and $\mathrm{Mo}_{0} \mathrm{Co}_{2} @ \mathrm{~N}-\mathrm{CNS} / \mathrm{CNT}$, respectively. The low Tafel slope of Mo2 $\mathrm{Co}_{1} @ N-C N S / C N T$ suggests its faster OER kinetics. Furthermore, EIS was used to investigate the OER kinetics over these electrocatalysts. The Nyquist plots given in Fig. 4c reveal that Mo2 $\mathrm{Co}_{1} @ N-C N S / C N T$ exhibits a much lower charge transfer resistance, which is indicative of faster electron transfer and thereby superior OER kinetics. All these results confirm that Co doping greatly boosts the intrinsic OER kinetics of molybdenum carbide. The long-term stability in the OER was evaluated by continuous operation at the current density of $20 \mathrm{~mA} \mathrm{~cm}^{-2}$, and the overpotential showed a small shift after $20 \mathrm{~h}$ of testing (Fig. 4d), which confirmed its good OER electrocatalytic durability.

Considering that Mo2 $\mathrm{Co}_{1} @ \mathrm{~N}-\mathrm{CNS} / \mathrm{CNT}$ can act as an effec- 

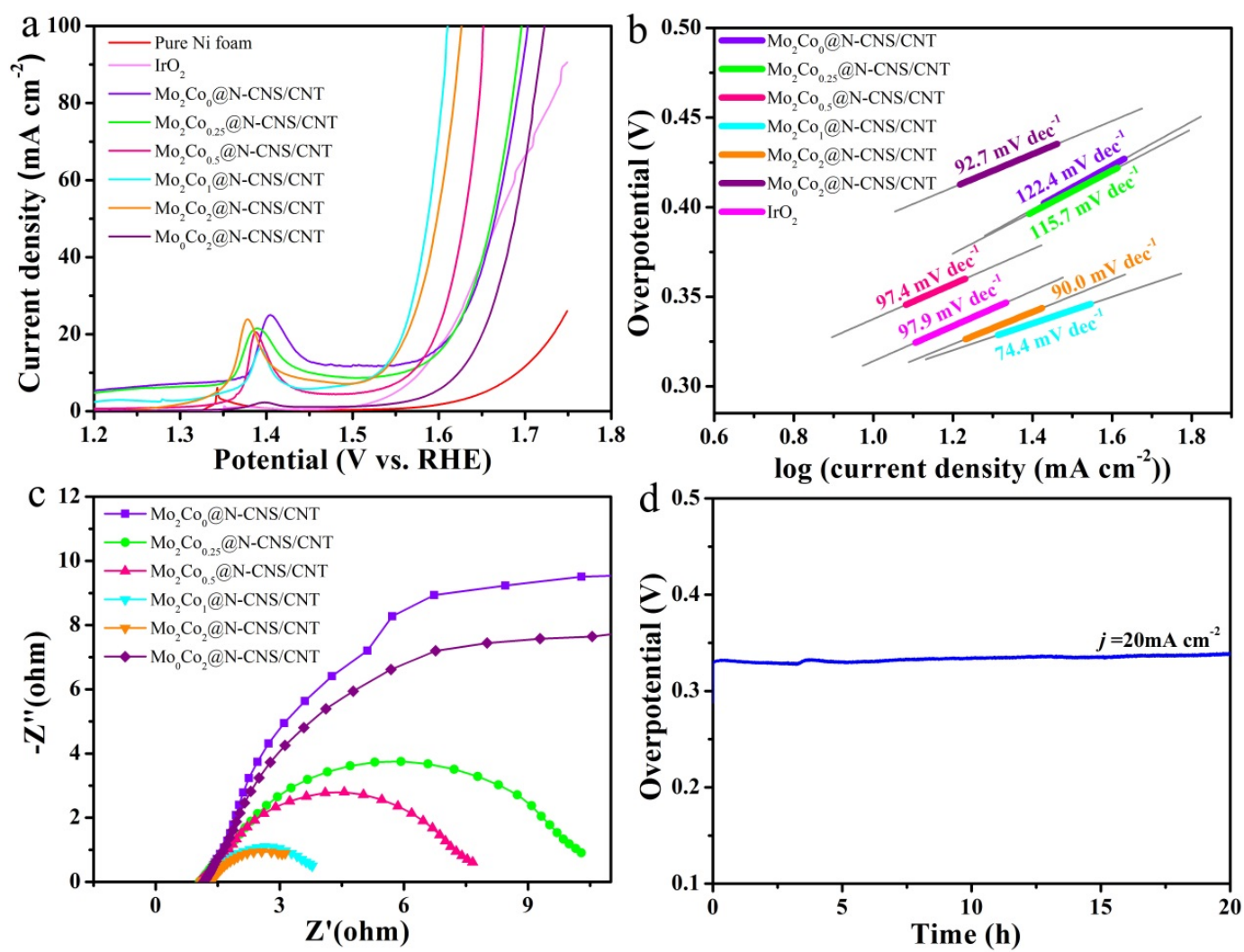

Fig. 4. Results of OER tests conducted in 1 mol L-1 KOH. (a) Polarization curves and (b) Tafel plots of $\mathrm{Mo}_{x} \mathrm{Co}_{y} @ \mathrm{~N}-\mathrm{CNS} / \mathrm{CNT}$, Ni foam, and IrO ${ }_{2}$ obtained at a scan rate of $5 \mathrm{mV} \mathrm{s}^{-1}$. (c) EIS Nyquist plots of $\mathrm{Mo}_{x} \mathrm{Co}_{y} @ \mathrm{~N}-\mathrm{CNS} / \mathrm{CNT}$ obtained at a potential of $0.49 \mathrm{~V}$. (d) Result of the stability test conducted on $\mathrm{Mo}_{2} \mathrm{Co}_{1} @ \mathrm{~N}-\mathrm{CNS} / \mathrm{CNT}$ at a current density of $20 \mathrm{~mA} \mathrm{~cm}^{-2}$.

tive and stable electrocatalyst for both the OER and HER in alkaline electrolytes, we speculate that it can be used as a bifunctional electrode for the overall water splitting. The overall water splitting performance was evaluated with a home-made electrolyzer by using the $\mathrm{Mo}_{2} \mathrm{Co}_{1} @ \mathrm{~N}-\mathrm{CNS} / \mathrm{CNT}$ as both the cathode and anode, along with employing pure Ni foam and commercial $\mathrm{IrO}_{2}-\mathrm{Pt} / \mathrm{C}$ as references; the corresponding polarization curves are displayed in Fig. 5a. Mo2 $\mathrm{Co}_{1} @ N-C N S / C N T$ can afford the current density of $10 \mathrm{~mA} \mathrm{~cm}^{-2}$ at a cell voltage of 1.63 $\mathrm{V}$, which is comparable with the performances of recently reported bifunctional water splitting electrocatalysts (Table S4). In contrast, the $\mathrm{Ni}$ foam presents negligible electrocatalytic activity. Furthermore, the long-term stability of the Mo2Co1@N-CNS/CNT electrolyzer system was evaluated by continuous operation at the current density of $20 \mathrm{~mA} \mathrm{~cm}^{-2}$ for $20 \mathrm{~h}$ (Fig. 5b). It can be found that the cell voltage displays negligible change, which suggests excellent stability and potential for development into real electrolyzer systems.

The superior catalytic activity of coupled Co-doped molybdenum carbide@N-doped carbon nanosheets/nanotubes can be ascribed to the following. (1) The direct growth of Co-doped molybdenum carbide@N-doped carbon nanosheets/nanotubes on the 3D conductive Ni foam substrate could avoid the use of polymer binders, thus enabling good mechanical adhesion, facilitating efficient transport of the electrolyte and electrons, and leading to more exposed active sites and faster release of bubbles. (2) The successful doping of Co into the MoC crystal structure could provide an optimized electronic structure, which further boosted the intrinsic activities for electrocatalytic HER $[24,25]$. (3) The chemical coupling of the OER-active Co with MoC could improve the OER activity of MoC. (4) The N atoms in the carbon nanosheets/nanotubes could effectively change the intrinsic chemical inertness and electronic structure of the adjacent $\mathrm{C}$ atoms and thus promote the adsorption of the intermediates of the water oxidation process $\left(\mathrm{OH}^{-}, \mathrm{OOH}^{-}\right)$ $[24,37]$.

\section{Conclusions}

Co-doped molybdenum carbide@N-doped carbon nanosheets/nanotubes were directly grown on 3D conductive Ni foam by a simple hydrothermal reaction first, which was
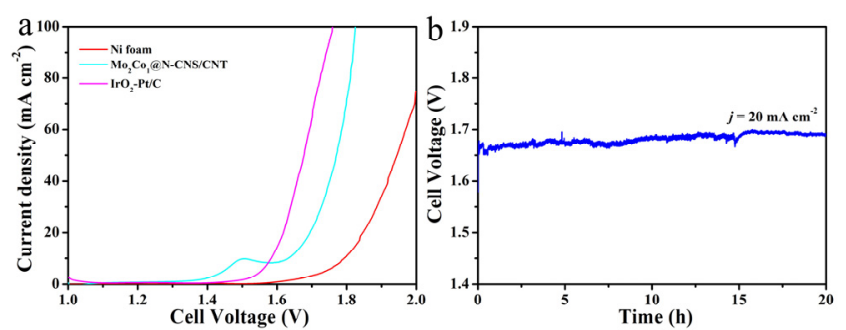

Fig. 5. Results of overall water splitting in $1 \mathrm{~mol} \mathrm{~L}^{-1} \mathrm{KOH}$. (a) Polarization curves of the overall water splitting in a two-electrode system. (b) Result of the stability test corresponding to overall water splitting at an applied current density of $20 \mathrm{~mA} \mathrm{~cm}^{-2}$. 
followed by a carburization treatment. The resulting Mo $2 \mathrm{Co}_{1} @ \mathrm{~N}-\mathrm{CNS} / \mathrm{CNT}$ exhibits a much higher activity toward both the HER and OER than Mo2Coo@N-CNS/CNT and $\mathrm{Mo}_{0} \mathrm{Co}_{2} @ \mathrm{~N}-\mathrm{CNS} / \mathrm{CNT}$, which can be attributed to the incorporation of Co into the MoC lattice, which results in an optimized electronic structure. The present finding provides a new strategy of designing and developing hybrid catalysts as attractive cost-effective materials for water splitting applications.

\section{References}

[1] J. Li, M. Yan, X. Zhou, Z. Q. Huang, Z. Xia, C. R. Chang, Y. Ma, Y. Qu, Adv. Funct. Mater., 2016, 26, 6785-6796.

[2] S. H. Ahn, I. Choi, H. Y. Park, S. J. Hwang, S. J. Yoo, E. Cho, H. J. Kim, D. Henkensmeier, S. W. Nam, S. K. Kim, J. H. Jang, Chem. Commun., 2013, 49, 9323-9325.

[3] C. Shi, A. J. Zhang, X. S. Li, S. H. Zhang, A. M. Zhu, Y. F. Ma, C. Au, Appl. Catal. A, 2012, 431-432.

[4] Y. Jiao, Y. Zheng, M. Jaroniec, S. Z. Qiao, Chem. Soc. Rev., 2015, 44, 2060-2086.

[5] M. R. Gao, J. X. Liang, Y. R. Zheng, Y. F. Xu, J. Jiang, Q. Gao, J. Li, S. H. Yu, Nat. Commun., 2015, 6, 5982.

[6] Y. F. Xu, M. R. Gao, Y. R. Zheng, J. Jiang, S. H. Yu, Angew. Chem. Int. Ed., 2013, 52, 8546-8550.

[7] C. C. L. McCrory, S. Jung, I. M. Ferrer, S. M. Chatman, J. C. Peters, T. F. Jaramillo, J. Am. Chem. Soc., 2015, 137, 4347-4357.

[8] X. M. Li, X. G. Hao, A. Abudula, G. Q. Guan, J. Mater. Chem. A, 2016, 4, 11973-12000.

[9] D. H. Youn, S. Han, J. Y. Kim, J. Y. Kim, H. Park, S. H. Choi, J. S. Lee, ACS Nano, 2014, 8, 5164-5173.

[10] Y. Li, H. X. Li, K. Z. Cao, T. Jin, X. J. Wang, H. M. Sun, J. X. Ning, Y. J. Wang, L. F. Jiao, Energy Storage Mater., 2018, 12, 44-53.

[11] X. J. Wang, Y. Li, T. Jin, J. Meng, L. F. Jiao, M. Zhu, J. Chen, Nano Lett., 2017, 17, 7989-7994.

[12] I. S. Amiinu, X. B. Liu, Z. H. Pu, W. Q. Li, Q. D. Li, J. Zhang, H. L. Tang, H. N. Zhang, S. C. Mu, Adv. Funct. Mater., 2018, 28, 1704638.

[13] X. F. Lu, L. F. Gu, J. W. Wang, J. X. Wu, P. Q. Liao, G. R. Li, Adv. Mater, 2017, 29, 1604437.

[14] H. Cheng, L. X. Ding, G. F. Chen, L. Zhang, J. Xue, H. Wang, Adv. Ma- ter., 2018, 30, 1803694.

[15] P. Xiao, X. M. Ge, H. B. Wang, Z. L. Liu, A. Fisher, X. Wang, Adv. Funct. Mater., 2015, 25, 1520-1526.

[16] Y. Zhao, K. Kamiya, K. Hashimoto, S. Nakanishi, J. Am. Chem. Soc., 2015, 137, 110-113.

[17] H. L. Lin, Z. P. Shi, S. N. He, X. Yu, S. N. Wang, Q. S. Gao, Y. Tang, Chem. Sci., 2016, 7, 3399-3405.

[18] L. Liao, S. N. Wang, J. J. Xiao, X. J. Bian, Y. H. Zhang, M. D. Scanlon, X. L. Hu, Y. Tang, B. H. Liu, H. H. Girault, Energy Environ. Sci., 2014, 7, 387-392.

[19] Z. W. Seh, K. D. Fredrickson, B. Anasori, J. Kibsgaard, A. L. Strickler, M. R. Lukatskaya, Y. Gogotsi, T. F. Jaramillo, A. Vojvodic, ACS Energy Lett., 2016, 1, 589-594.

[20] F. X. Ma, H. B. Wu, B. Y. Xia, C. Y. Xu, X. W. Lou, Angew. Chem. Int. Ed., 2015, 54, 15395-15399.

[21] H. B. Wu, B. Y. Xia, L. Yu, X. Y. Yu, X. W. Lou, Nat. Commun., 2015, 6, 6512.

[22] J. Greeley, T. F. Jaramillo, J. Bonde, I. B. Chorkendorff, J. K. Norskov, Nat. Mater., 2006, 5, 909-913.

[23] R. Michalsky, Y. J. Zhang, A. A. Peterson, ACS Catal., 2014, 4, 1274-1278.

[24] T. Ouyang, Y. Q. Ye, C. Y. Wu, K. Xiao, Z. Q. Liu, Angew. Chem. Int. Ed, 2019, 58, 4923-4928.

[25] H. L. Lin, N. Liu, Z. P. Shi, Y. L. Guo, Y. Tang, Q. S. Gao, Adv. Funct. Mater., 2016, 26, 5590-5598.

[26] M. Bajdich, M. García-Mota, A. Vojvodic, J. K. Nørskov, A. T. Bell, J. Am. Chem. Soc., 2013, 135, 13521-13530.

[27] H. Chen, L. F. Hu, M. Chen, Y. Yan, L. M. Wu, Adv. Funct. Mater., 2014, 24, 934-942.

[28] Y. S. Jin, H. T. Wang, J. J. Li, X. Yue, Y, J. Han, P. K. Shen, Y. Cui, Adv. Mater., 2016, 28, 3785-3790.

[29] Y. Y. Jiang, Y. Z. Lu, J. Y. Lin, X. Wang, Z. X. Shen, Small Methods, 2018, 2, 1700369.

[30] R. G. Ma, Y. Zhou, Y. F. Chen, P. X. Li, Q. Liu, J. C. Wang, Angew. Chem. Int. Ed., 2015, 54, 14723-14727.

[31] J. Jiang, Q. X. Liu, C. M. Zeng, L. H. Ai, J. Mater. Chem. A, 2017, 5, 16929-16935.

[32] Y. N. Regmi, C. Wan, K. D. Duffee, B. M. Leonard, ChemCatChem, 2015, 7, 3911-3915.

[33] M. J. Kim, S. Kim, D. H. Song, S. K. Oh, K. J. Chang, E. A. Cho, Appl.

\section{Graphical Abstract}

Chin. J. Catal., 2019, 40: 1352-1359 doi: S1872-2067(19)63406-6

\section{Coupled cobalt-doped molybdenum carbide@N-doped carbon nanosheets/nanotubes supported on nickel foam as a binder-free electrode for overall water splitting}

Jiangnan Xing, Fei Lin, Liutao Huang, Yuchang Si *, Yijing Wang, Lifang Jiao * Nankai University; Logistics University of People's Armed Police Force

We propose a facile and controllable strategy to develop highly efficient and stable Co-doped MoC@N-doped carbon nanosheets/nanotubes by direct growth on 3D conductive Ni foam as a self-supported electrode for both the HER and OER.

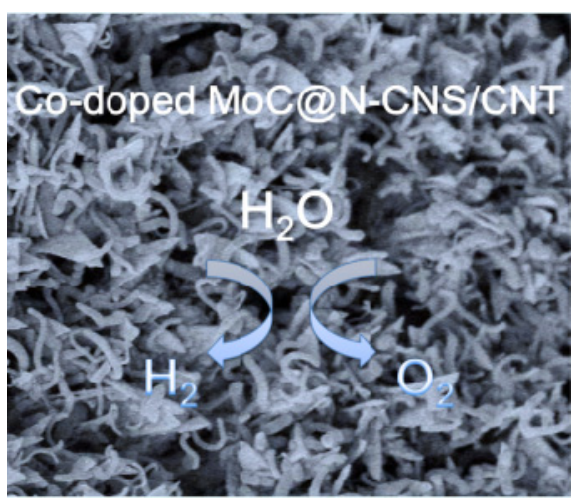


Catal. B, 2018, 227, 340-348.

[34] Q. R. Liang, H. H. Jin, Z. Wang, Y. L. Xiong, S. Yuan, X. C. Zeng, D. P. He, S. C. Mu, Nano Energy, 2019, 57, 746-752.

[35] A. Sivanantham, P. Ganesan, S. Shanmugam, Adv. Funct. Mater., 2016, 26, 4661-4672.
[36] J. N. Xing, Y. Li, S. W. Guo, T. Jin, H. X. Li, Y. J. Wang, L. F. Jiao, Electrochim. Acta, 2019, 298, 305-312.

[37] Y. P. Liu, G. T. Yu, G. D. Li, Y. H. Sun, T. Asefa, W, Chen, X. X Zou, Angew. Chem. Int. Ed., 2015, 54, 10752-10757.

\title{
泡沫镍负载Co-MoC@N-CNS/CNT作为自支撑电极用于全水分解
}

\author{
邢江南 ${ }^{\mathrm{a}}$, 林 斐 ${ }^{\mathrm{a}}$, 黄柳蹈 ${ }^{\mathrm{a}}$, 司玉昌 ${ }^{\mathrm{b}, * *}$ ，王一菁 ${ }^{\mathrm{a}}$, 焦丽芳 ${ }^{\mathrm{a},}$ \\ a南开大学化学学院先进能源材料化学教育部重点实验室, 天津 300071 \\ ' 中国人民武装警察部队后勤学院，天津300309
}

\begin{abstract}
摘要: 在众多的过渡金属催化剂中, 碳化钿因具有类贵金属电子结构、高电子导电性、宽pH适用范围, 优异的催化活性和 稳定性等优点受到科研工作者的广泛关注. 密度泛函理论计算(DFT)得出的“火山图”表明碳化钿具有较强的氢吸附能, 而 Co 具有较弱的氢吸附能. 已有报道指出将Co 与碳化钿化学耦合能够促使其展现相对适中的氢吸附能, 从而提高材料的本 征催化活性. 此外, 碳化钿很少被认为是一种氧析出反应催化剂, 而 $\mathrm{Co}$ 则被广泛认为是高效且稳定的碱性水分解析氧催化 剂. 基于此, 我们提出化学耦合 $\mathrm{C}$ 与碳化钼能够同时提升材料的析氧催化性能. 值得一提的是, 自支撑材料可直接用作工 作电极以避免粘结剂(覆盖活性位, 阻碍催化过程中传质的发生, 增加电子转移阻抗)的使用. 然而, 目前关于自支撑碳化钿 催化剂的研究鲜有报道.

本文采用简单的水热法制备了泡沫镍负载钴掺杂碳化钿耦合的碳纳米片和碳纳米管(Co-MoC@N-CNS/CNT)自支撑 电极. 通过X射线粉末衍射(XRD)、扫描电镜(SEM)、透射电镜(TEM)、X射线和紫外光电子能谱(XPS、UPS)等表征手段 对产物形貌结构进行了表征, 利用电化学工作站对其水分解催化性能进行了研究. 通过调控前驱体制备时的钴源浓度得到 了一系列不同 $\mathrm{Co}$ 掺杂量的样品. UPS测试表明, $\mathrm{Co}$ 成功掺杂到 $\mathrm{MoC}$ 晶体结构中能够显著增加其费米能级附近的电子密度, 从而优化其HER动力学. 与纯相的 $\mathrm{MoC}$ 和 $\mathrm{Co}$ 单质相比, 掺杂后样品的催化活性得到显著提升. 其优异的电化学活性可归结 为如下几点: (1) $2 \mathrm{D}$ 纳米片和 $1 \mathrm{D}$ 纳米线交错形成的 $3 \mathrm{D}$ 纳米结构可有效暴露更多的活性位点和促进电子转移; (2) Co掺杂能 够优化 $\mathrm{MoC}$ 晶体结构费米能级附近的电子结构, 从而提升其HER动力学; (3) N-CNS/CNT不仅能够保护Co和MoC免于碱性 腐蚀, 还能促进纳米颗粒和碳基质间快速的电子传递.

上述结果表明, 通过合理设计碳化钼的组成和纳米结构可获得具有高活性和稳定性的双功能催化剂, 为高性能催化剂 的开发和利用开辟了新的途径.
\end{abstract}

关键词: 碳化钿; 钴掺杂; 自支撑电极; 全水分解

收稿日期: 2019-03-31. 接受日期: 2019-05-10. 出版日期: 2019-09-05.

*通讯联系人. 电话/传真: (022) 23504527; 电子信箱: jiaolf@nankai.edu.cn

**通讯联系人. 电话/传真: (022) 84876282; 电子信箱: siyuch@163.com

基金来源: 国家自然科学基金(51622102, 51571124, 21421001); 高等学校学科创新引智计划(111计划, B12015); 天津市自然科学 基金(18ZXJMTG00040, 16PTSYJC00030); 中央高校基本科研业务费专项资金.

本文的电子版全文由Elsevier出版社在ScienceDirect上出版(http://www.sciencedirect.com/science/journal/18722067). 